\title{
MULHERES NA COLONIZAÇÃO BRASILEIRA: RELEITURAS FICCIONAIS POR UM PRISMA FEMININO - A CRITICIDADE DO ROMANCE HISTÓRICO CONTEMPORÂNEO DE MEDIAÇÃO
}

\author{
WOMEN IN THE BRAZILIAN COLONIZATION: FICTIONAL REREADINGS \\ THROUGH A FEMININE PERSPECTIVE - THE CRITICAL NATURE OF THE \\ CONTEMPORARY HISTORICAL NOVEL OF MEDIATION
}

\section{Beatrice Uber ${ }^{1}$ Patrícia de Oliveira ${ }^{2}$}

\begin{abstract}
Resumo: As obras híbridas de história e ficção Desmundo (1996), de Ana Miranda, e A mãe da mãe da sua mãe e suas filhas (2002), de Maria José Silveira, evidenciam o prisma de personagens femininas protagonistas que atuam em diferentes episódios ao longo do período da colonização brasileira. Outrora, já foram mulheres depreciadas, agora, pelo discurso ficcional, ganham a oportunidade de redefinir o imaginário do processo de colonização do Brasil por meio da escrita de autoria feminina contemporânea. Esse estudo conta com o suporte teórico de perspectivas evidenciadas nos estudos de Branco (1991), Fleck (2007; 2017), e Zolin (2009), entre outros.
\end{abstract}

Palavras- chave: Desmundo (1996); A mãe da mãe da sua mãe e suas filhas (2002); romance histórico contemporâneo de mediação; autoria feminina; colonização brasileira.

Abstract: The literary works of history and fiction Desmundo (1996), by Ana Miranda, and $A$ mãe da mãe da sua mãe e suas filhas (2002), by Maria José Silveira, highlight the perspective of female protagonist characters that take part in different moments along the Brazilian colonization

\footnotetext{
${ }^{1}$ Graduada em Letras Português/Inglês pela Universidade Estadual do Oeste do Paraná, campus de Cascavel, em 2013; especialista em Língua Inglesa: Estudos Linguísticos, Literários e Culturais pelo Centro Universitário da Fundação Assis Gurgacz em 2016; mestra na área de Linguagem Literária e Interfaces Sociais: Estudos Comparados e Literatura pela Unioeste, campus de Cascavel, em 2017; Doutoranda na área de Linguagem Literária e Interfaces Sociais: Estudos Comparados e Literatura pela Unioeste, campus de Cascavel. Integrante do grupo de pesquisa "Ressignificações do passado na América Latina: leitura, escrita e tradução de gêneros híbridos de história e ficção vias para a descolonização", liderado pelo Prof. Dr. Gilmei Francisco Fleck. Colaboradora do projeto de extensão "Estudos das teorias contemporâneas de análise literária", vinculado ao PELCA - Programa de Ensino de Literatura e Cultura/PROEX-Unioeste-Cascavel. E-mail: bea_uber@hotmail.com

${ }^{2}$ Graduada em Letras Português/Inglês e respectivas literaturas pela Universidade Estadual do Paraná-Campus de Campo Mourão (UNESPAR/FECILCAM) concluída no ano de 2012. Especialista em Psicopedagogia Clínica e Institucional (2014) pela FATEC e em Ensino de Sociologia no Ensino Médio (2016) pela UNICENTRO. Mestra em na área de Linguagem Literária e Interfaces Sociais: Estudos Comparados e Literatura pela Unioeste, campus de Cascavel, em 2019. Integrante do grupo de pesquisa "Ressignificações do passado na América Latina: leitura, escrita e tradução de gêneros híbridos de história e ficção - vias para a descolonização", liderado pelo Prof. Dr. Gilmei Francisco Fleck. Colaboradora do projeto de extensão "Estudos das teorias contemporâneas de análise literária", vinculado ao PELCA - Programa de Ensino de Literatura e Cultura/PROEX-Unioeste-Cascavel. E-mail: pat.oliveirah@gmail.com
} 
period. Formerly portrayed as women who were depreciated, now, through the fictional discourse, they have the opportunity to redefine the colonizing imaginary process of the colonization in Brazil throughout the contemporary women-authored writing. This scientific paper relies on the theoretical support of the perspectives highlighted in the studies of Branco (1991), Fleck (2007; 2017), and Zolin (2009), among others.

Keywords: Desmundo (1996); A mãe da mãe da sua mãe e suas filhas (2002); contemporary historical novel of mediation; women-authored writing; Brazilian colonial period.

\section{Introdução}

A história e a literatura foram áreas que estiveram conectadas por muito tempo e consideradas "ramos da mesma árvore do saber, uma árvore que buscava 'interpretar a experiência, com o objetivo de orientar e elevar o homem"” (HUTCHEON, 1991, p. 141). Hutcheon (1991, p. 143) afirma que "a história e a ficção sempre foram conhecidas como gêneros permeáveis. Em várias ocasiões, as duas incluíram em suas elásticas fronteiras formas como o relato de viagem e diversas versões daquilo que hoje chamamos de sociologia." Um exemplo desta escrita é "A carta de Pero Vaz de Caminha" (CASTRO, 2008) na qual se narra o "descobrimento" das terras hoje brasileiras na América e as primeiras impressões sobre elas e seus habitantes a partir de um ponto de vista masculino. Esse relato é explorado tanto pela historiografia quanto pela ficção. Logo, neste texto, atentamos para o fato de que ambas as leituras são oriundas das construções linguísticas e se diferenciam pelas convenções que regem seus discursos: veracidade e verossimilhança, conforme defende Milton (1992).

Segundo Pesavento (1999), a escrita da história organiza os acontecimentos e transmite-os àqueles que não os vivenciaram e estes - sejam leitores ou ouvintes - os tomam como um discurso verídico. Já a ficção é vista “como ato ou efeito de 'colocar no lugar de', 'dar o efeito de real', como se aquilo que se passou longe do olhar e da vida dos ouvintes ali estivesse, numa ‘ilusão referencial' de presença e que permitisse o público 'imaginar' como 'teria sido' aquilo que se narra." (PESAVENTO, 1999, p. 819-820). Isto posto, observamos que a literatura híbrida de história e ficção se aproveita, em várias de suas modalidades, da verossimilhança para criar, nesse seu espaço imaginário, aquilo que a história não quis ou não pôde revelar por diversos motivos ao seu leitor/ouvinte. 
Entre as escritas híbridas de história e ficção, voltamo-nos aos romances históricos. Estas são obras de ficção nas quais, para Mata Induráin (1995), o elemento "histórico" inserido na tessitura discursiva é o adjetivo e o "romance", com todas as premissas de sua liberdade de imaginação e criação, é o substantivo. A ordem desses termos já evidencia que se trata de um processo criacional imaginativo. Os autores ou autoras de romances históricos mesclam fatos e personagens num tecido narrativo que pode ser considerado tradicional, quando nele se valoriza os eventos apresentados pela historiografia oficial, além de haver uma exaltação daquelas personagens consideradas heróis, ou, ainda, críticas e desconstrucionistas, quando neles se traz à tona versões que contestam o prisma dos detentores do poder - homens brancos, cristãos e europeus que comandaram as ações de descobrimento, conquista e colonização da América. Sujeitos que, por já dominarem a escrita no período do descobrimento das terras americanas no final do século VX, registram a sua única versão deste passado, num processo típico do eurocentrismo ${ }^{3}$.

Se ao longo de grande parte de nossa história os fatos levados em consideração eram sempre apresentados ao mundo e narrados pelo ponto de vista masculino, com o passar do tempo isso foi sendo transformado. As mulheres, que antes eram solapadas pelo discurso histórico, lutaram para que sua escrita fosse considerada válida e, também, oficial. Nas últimas décadas, em especial, a produção literária de autoria feminina tem mostrado que mulher é capaz de escrever em relação de igualdade com o homem.

Com o intuito de elaborar uma teoria que desse conta de aspectos peculiares da escrita feminina, Branco (1991, p. 11) parte da ideia de que "feminino é um adjetivo relacionado, direta ou indiretamente, à mulher." Para essa autora, não se trata de "atribuir uma categorização sexual à escrita” (BRANCO, 1991, p. 11), ou de um texto que possa revelar aspectos fisiológicos ou psíquicos de seu autor, mas, talvez, um "lugar limítrofe entre o sexual e o além-sexual" (BRANCO, 1991, p. 12). Além disso, a teórica supracitada explica que não devemos entender a escrita feminina como algo apenas produzido por mulheres, por causa do adjetivo, mas, sim, como algo que acontece porque é relativo às mulheres. Com isso, vemos que o espaço literário é

\footnotetext{
${ }^{3}$ Aníbal Quijano (2005, p. 126) define o termo eurocentrismo como "o nome de uma perspectiva de conhecimento cuja elaboração sistemática começou na Europa Ocidental antes de mediados do século XVII, ainda que algumas de suas raízes são sem dúvida mais velhas, ou mesmo antigas, e que nos séculos seguintes se tornou mundialmente hegemônica percorrendo o mesmo fluxo do domínio da Europa burguesa.”
} 
lugar de confluências, pois nele diversas vozes femininas se encontram não para reduplicar o ideal das narrativas masculinas, mas para transitar entre seus sentimentos, opiniões, decisões e atitudes tomadas. Estas podem a levar a uma linguagem distinta: a de se afirmar como pessoa de valor perante as inúmeras marginalizações sofridas.

Ao romper o ciclo canônico de escrita masculina - que mostrava a mulher sempre como um objeto descrito, passiva aos ideais masculinos e que era culpada por transgredir as ordens da moralidade, fossem elas espaciais ou sexuais -, imposta pela cultura eurocêntrica, autoras como Ana Miranda, com o romance Desmundo (1996), e Maria José Silveira, com A mãe da mãe da sua mãe e suas filhas (2002), colocam em evidência personagens femininas que representam essas mulheres outrora silenciadas e depreciadas, mas que, agora, pelo discurso ficcional, podem expressar-se por meio da arte literária e redefinir o processo de colonização brasileira.

Em seguida, propomos-nos a tecer considerações sobre os romances previamente mencionados, com o intuito de apresentar o prisma das personagens femininas que não figuraram na estante oficial da história, mas que, nesse novo cruzamento de vozes, podem reler alguns eventos e reescrever outros momentos históricos. Acreditamos que tais obras podem abrir portas para se entrever protagonismos femininos durante o período colonial e os anos que se sucederam. Embora o relato de muitas mulheres tenha sido sufocado naquele período, a distância temporal vem nos mostrar que deslocar-se da margem para o "entre-lugar do discurso latino-americano" é possível também para as mulheres.

\section{Desmundo (1996): viés feminino e descolonizador do romance histórico contemporâneo de mediação}

O romance histórico Desmundo (1996), de Ana Miranda, aborda a temática das órfãs d'elRei, também conhecidas como “órfãs da rainha". Costa (1946) informa que quando o Padre Nóbrega lançou seus olhos sobre as terras brasileiras, ele se deu conta de que os homens responsáveis pelas colônias em desenvolvimento não se comportavam com a dignidade de um branco europeu como se esperava. Ocorria na colônia, as vistas do clérigo, uma mistura de raças entre os homens brancos e as mulheres nativas que habitavam o território, uniões clandestinas não abençoadas pela Igreja Católica - e nasciam filhos bastardos dessas relações, que também 
não eram desejadas pela Coroa Portuguesa. Era possível notar que esse tipo de comportamento colocava em risco o plano de se obter e desenvolver um novo território português pela cultura portuguesa. A hegemonia, termo que entendemos como a supremacia de um povo sobre outro, não seria mantida. Logo, para resolver tal questão, o Padre Nóbrega requisitou ao rei de Portugal que enviasse mulheres brancas para se unirem em matrimônio aos homens residentes nas colônias portuguesas. Conforme as palavras do representante da Igreja: "quaisquer mulheres, ainda que sejam erradas." (COSTA, 1946, p. 105). Observamos que a cor da pele era um fator altamente decisivo nessa nova edificação geográfica portuguesa, já a conduta moral até poderia ser relegada a segundo plano desde que a raça branca prevalecesse; e, assim, nesse processo de dominação inferiorizava-se o habitante nativo, sua cor, sua língua e sua cultura.

Segundo Costa (1946), julgando a necessidade de seu plano de implantação no "Novo Mundo" - as terras sendo "descobertas" e conquistadas pela Europa, nesse caso, Portugal - o Rei D. João III enviou um número razoável de órfãs para a região da Bahia, com o intuito de desposar esses desbravadores, entre os anos de 1551 e 1608/1609. Essas jovens, consideradas órfãs e que estavam sob a tutela do rei e da rainha portuguesa, eram as "filhas, netas, irmãs e sobrinhas de homens que tivessem morrido a serviço da coroa. Eram escolhidas no Reino e não só recompensadas com dotes no além-mar, como também de atribuição de postos de menor importância na burocracia do império de seus futuros maridos [...].” (ALMEIDA, 2003, p.157).

Almeida (2003) explica que para ser considerada uma órfã d'el-Rei era necessário ser órfã de pai e mãe, porém filha de um legítimo matrimônio. Era necessário estar em boa condição física, pois o Recolhimento do Castelo, local onde eram abrigadas até se casarem, não aceitava moças doentes, cegas ou aleijadas. Ademais, deveriam ser jovens e estar em idade entre 12 e 30 anos para poder procriar e gerar filhos brancos.

Quando as órfãs estavam em viagem, Ramos (2007, p. 34) expõe que elas - virgens destinadas ao matrimônio - estavam suscetíveis a estupros. Por conta disso, "alguns religiosos tomavam sua guarda, principalmente quando se tratava de meninas menores de 16 anos." Após o ano de 1608/1609, devido a um “mal” ocorrido com as órfãs, não se teve mais notícias de algum envio, afirma Garcia (1946). Contudo, de uma maneira geral, Garcia (1946, p. 111) declara que as órfãs enviadas foram casadas "com homens que eram proprietários, agricultores, fazendeiros, 
funcionários públicos de maior representação, foram realmente a grande força de constituição e desenvolvimento da família ou da sociedade brasileira." Como resultado da informação apresentada, podemos acreditar que o envio dessas órfãs ajudou no estabelecimento das desejadas famílias pelo império português: famílias de raça branca e cristãs católicas.

Essa temática cruzou a barreira disciplinar da história e estendeu-se ao campo literário. Agora, quem apresenta essa narrativa é a jovem órfã Oribela de Mendo Curvo, uma personagem fictícia que revisita esse campo histórico e narra, em primeira pessoa, sua viagem ao Brasil e a de mais seis outras órfãs da rainha. Ela revela, no romance, seu olhar e impressões sobre a colônia em desenvolvimento, seu matrimônio, sua vida de casada ao lado do marido, seu processo de adaptação em terras brasileiras, seu caso amoroso com a personagem Ximeno Dias, o nascimento do filho e o abandono de seu esposo. O local onde a história se passa é uma capitania, em algum lugar do nordeste brasileiro, em meados do século XVI, mas não há uma data específica mencionada ao longo da obra. Por meio do relato desta personagem protagonista, o leitor passa a ter uma visão diferenciada dos acontecimentos dos primórdios da colonização brasileira. É uma visão não reduplicada do ponto de vista masculino que vai se desenvolvendo ao longo da trama fictícia e que, por isso, inclui seu discurso em muitos momentos na fase feminista da literatura de autoria feminina, conforme Zolin (2009). Uma fase que não mais internaliza e reproduz os padrões dominantes, mas que protesta contra tais paradigmas.

A trajetória linear do evento histórico recriado no romance Desmundo (1996) evidencia que os acontecimentos ocorrem de forma ordenada e isso se configura como uma das características da mais nova modalidade de romance histórico: o romance histórico contemporâneo de mediação, segundo a nomenclatura que Fleck (2007) introduz no campo crítico para diferenciar essa mais recente modalidade das escritas híbridas de história e ficção. Nos estudos recentes de Fleck (2017), o teórico destaca as fases e modalidades do romance histórico, observando que

[...] a leitura ficcional do passado compreendida pelo romance histórico contemporâneo de mediação busca seguir a linearidade cronológica dos eventos na diegese, fixando-se neles para assegurar o avanço da narrativa. Contudo, não se deixa de manipular o tempo da narrativa, promovendo retrospectivas ou avanços nesta pelo emprego de analepses e prolepses. Tal manipulação não se configura, contudo, em anacronias exageradas ou sobreposições de diferentes tipos históricos ou narrativos na tessitura do romance [...]. (FLECK, 2017, p. 110). 
Um exemplo dessas anacronias presentes na obra de Miranda (1996) pode ser visto pelo leitor na narrativa quando a personagem Oribela se recorda dos banhos de sua infância e o fato de seu pai ordenar a colocação de leite na água do banho para que seu corpo não estivesse em evidência: "Meu pai mandava turvar a água do banho com leite para não ver o meu corpo de criança, uma vez alevantei da gameleira e ele me castigou com tantas vergastadas que verti sangue pela boca.” (MIRANDA, 1996, p. 43). Essas analepses são lembranças de um passado recente, levando-se em conta que a personagem Oribela está configurada como uma jovem com menos de vinte anos de idade, "a de menos anos de vida entre as órfãs." (MIRANDA, 1996, p. $63)$.

É possível observar que, em um primeiro momento do romance, a ideologia presente nas falas da protagonista Oribela exalta as ideias contidas e difundidas pela historiografia tradicional: a personagem não só acredita em seu valor de mulher branca e virgem como, também, ostenta o fato de ser uma órfã da rainha. Ela menciona que as mulheres nativas do local olhavam às jovens órfãs recém-chegadas como se tivessem birra delas e estivessem pasmas pela sua presença. Depois, sente-se ainda mais exaltada quando relata "de pobre éramos ricas, de um tipo de cabedal nascido de nossa própria natureza, feito uma boa terra para plantar, ou uma mulher feia de alma boa." (MIRANDA, 1996, p. 42) e termina dizendo que o governador desejava "o melhor para as bodas das órfãs de dona Catarina, mandou baterem édito, que os noivos se apressassem a se apresentar, homens de muita honra, coração tornado em alteza pelo alvidro de seus feitos, para tais mulheres formosas [...].” (MIRANDA, 1996, p. 51). Todo esse discurso revela a natureza europeia colonizadora da personagem num primeiro momento do relato.

A personagem desembarca nesse "Novo Mundo" com ideais pré-estabelecidos sobre sua condição física - mulher cristã e branca - e considera isso valioso, pois acredita, cegamente, serem estes os únicos valores corretos. Entretanto, sua percepção desse local e das pessoas que ali residem vai se transformando e isso não demora muito para ocorrer. Logo, sua visão convencional sobre a realidade da nova colônia vai dissolvendo-se e transformando em olhares críticos acerca da história da colonização e da vinda das "órfãs da rainha". Prontamente, esse fato também evidencia uma característica do romance histórico contemporâneo de mediação definido 
por Fleck (2017), pois, ao recriar ficcionalmente um evento do passado, essa modalidade consegue manter

[...] o intento da construção da verossimilhança, em grande medida abandonada pelas narrativas do novo romance histórico hispano-americano e da metaficção historiográfica, para conferir um tom de autenticidade aos eventos históricos renarrativizados no romance, a partir de perspectivas periféricas, ancoradas em narradores personagens antes vistos como secundários ou esquecidos pelo discurso historiográfico. (FLECK, 2017, p. 109-110).

As releituras críticas da personagem órfã da rainha, Oribela, começam a ser expostas quando ela comenta a procedência de algumas dessas "brancas, católicas, portuguesas": “As enjeitadas, as fideputas, que nem se rapta nem se dota, mulher de cafraria. Que teve a rainha de dotar e o rei dar ofício. Mulher de pele branca e fala em bom português. [...] esta ademais de jovem é mestre na potagem de coelhos.” (MIRANDA, 1996, p. 52). Assim, evidencia-se que algumas dessas jovens eram tão "ruins" que, em Portugal, nem seriam raptadas ou que já tinham experiências sexuais, uma vez que procriavam como coelhos, isto é, inúmeras vezes. O prisma de uma mulher que não tinha voz durante a colonização surge para explorar criticamente a temática das órfãs da rainha. Consequentemente, tal visão contestadora, de protesto contra padrões e valores estipulados e difundidos, coloca o ponto de vista da jovem na fase feminista da literatura de autoria feminina, segundo Zolin (2009).

Consoante essa autora, tal fase, conforme foi estudada por Elaine Showalter em $A$ literature of their own: British novelists from Brontë to Lessing (1985), evidencia uma ruptura com a fase feminina, que imitava os padrões dominantes masculinos da época. Showalter (1985), segundo Zolin (2009), observou que os padrões da literatura de autoria feminina passavam por mudanças de padrões, temas, problemas e imagens; e que isso ocorria porque que a sociedade em que ela estava inserida também passava por mudanças políticas, econômicas e culturais. Zolin (2009) explana igualmente que os grupos minoritários, como era o caso das mulheres, “construíram sua tradição literária a partir das relações ainda em desenvolvimento, travadas com a sociedade maior em que se inserem.” (ZOLIN, 2009, p. 329-330).

A protagonista, Oribela, cumpre o objetivo de sua ida ao "Novo Mundo" e casa-se com a personagem de extração histórica Francisco de Albuquerque, um homem de alta casta dentro da 
colônia, que além de ser sobrinho de Dona Brites, a mulher do governador, era também dono de uma grande propriedade em terra e servos - os habitantes nativos - ela vai apresentando os desgostos de sua vida matrimonial.

Inicialmente, a personagem mostra repulsão por aquele homem que se tornaria seu esposo. "Seu aspecto era o de um cão danado, lhe faltavam dentes, tinha pernas finas, nariz quebrado, [...] a pele de seu semblante parecia uma pedra lavrada, corroída pelas ventanias e pelas formigas.” (MIRANDA, 1996, p. 35). Além da péssima aparência, no desenrolar da narrativa, Oribela descobre que seu marido não era um exemplo de honestidade porque ele havia matado cerca de oitenta mouros em suas viagens buscando fortuna e "fora seis vezes preso, doze vezes ferido, duas cativo e duas vendido, nas partes da Índia." (MIRANDA, 1996, p. 129). Até carne humana tinha degustado: "Das comidas todas comera neste mundo, formigas ou virtualhas divinas, comera cafres, mouros e até um cristão, um português morto, magro e de carne amarga." (MIRANDA, 1996, p. 130). Ao relatar tais experiências, a protagonista sente mais medo de seu marido e imagina estar abandonada por Deus naquele local, pois exterioriza "estando eu no desmundo" (MIRANDA, 1996, p. 138), que, para ela, acolhe os desvalidos do mundo e os excluídos do bom convívio com a sociedade europeia, um lugar que "não é mundo civilizado".

O relato da personagem Oribela sobre a deslealdade de seu esposo com outras mulheres é evidenciado no seguinte trecho: "Francisco de Albuquerque as tinha em seus desejos, que me fazia ver e ouvir, pelos lumes acesos e pelas vozes." (MIRANDA, 1996, p. 131). Essa personagem masculina utiliza de sua prerrogativa de homem branco, detentor do poder e da palavra, para impor ordem e medo em sua esposa. Um ideal assim parte do conceito de androcentrismo pois, segundo Bourdieu ([1998] 2014, p. 18), "a força da ordem masculina se evidencia no fato de que ela dispensa justificação: a visão androcêntrica impõe-se como neutra e não tem necessidade de se enunciar em discursos que visem legitimá-la.” Tal exemplo da conduta do homem representado como Francisco, esposo de Oribela, nos leva a crer que a proteção e a influência da Igreja para com as jovens órfãs vigoravam até a cerimônia matrimonial, mas, além disso, não havia envolvimento algum por parte da classe eclesiástica e a mulher deveria ser recatada e subordinada ao seu esposo. 
A protagonista do romance Desmundo (1996) não se abate pelo espaço limitado que o marido tenta lhe impor e rebela-se contra ele. Insatisfeita com sua vida de casada, ela tenta duas fugas com o intuito de regressar a Portugal e livrar-se da servidão masculina. Na sua segunda fuga, Oribela não tem medo de romper com padrões estabelecidos e se disfarça de homem, cortando o cabelo e jogando suas roupas foras quando a propriedade de seu esposo, Francisco, foi atacada por nativos que se rebelavam contra o sistema de servidão-escravidão que o "Velho Mundo" - a Europa - lhes impunham. Assim sendo, num ato de rebeldia, ela diz, "[...] com a faca que tomei à cozinha cortei meus cabelos bem tosados, joguei-os no fogo com as roupas minhas e sem me deterem por ver sem saberem do vulto de homem ser mulher montei um cavalo e me arremessei pelos caminhos [...]." (MIRANDA, 1996, p. 156).

Durante a época do período colonial, as mulheres deveriam ter cabelos compridos, pois isso evidenciava sua feminilidade. Sobre essa ideia, Perrot ([2006] 2012) menciona que a mulher é uma imagem, feita de aparências, e que o seu cabelo tem a capacidade de diluir ou encorpar sedução. "Raspar os cabelos de alguém, homem ou mulher, é tomar possessão dele ou dela, é torná-lo anônimo [...]." (PERROT, 2012, p. 52).

No relato do romance, ao tentar escapar do domínio masculino - e após ter desmaiado de exaustão devido a sua longa caminhada - a protagonista é socorrida pelo mouro Ximeno Dias que a abriga em sua casa. Ambos se envolvem em um caso amoroso e ela engravida desse jovem mercador. Contudo, na sequência das ações, vemos que, passados alguns dias, Francisco encontra sua mulher e a leva de volta para casa.

Com base na conduta desta figura masculina, mencionamos o que Vainfas (2011) afirma sobre a sujeição das mulheres no Brasil colonial. Para esse autor, as jovens viviam "em completa sujeição, primeiro aos pais, os todos poderosos senhores de engenho, depois aos maridos." (VAINFAS, 2011, p. 115). É a partir de um foco narrativo que "privilegia visões a partir das margens, sem concentrar-se em grandes personagens da história [que] a voz enunciadora do discurso é fixada pelo foco único, manifestando-se em nível intradiegético e voz homo ou autodiegética, subjetivando o material histórico incluído na diegese" (FLECK, 2017, p. 110), que o romance histórico contemporâneo de mediação outorga o direito à palavra a uma voz feminina que busca afirmar-se perante o leitor e o mundo. Uma vez que Miranda (1996) centraliza sua obra 
nessa figura feminina, temos outra característica do romance histórico contemporâneo de mediação: personagens centrais, famosos e amplamente conhecidos pela história tradicional precisam dividir o palco fictício com personagens secundários, os chamados ex-cêntricos, aqueles que revelam-se com histórias e perspectivas "vistas de baixo" (SHARPE, 2011), que não corroborava com a difusão de uma história "vista de cima", um prisma tradicional eurofalocêntrico.

O discurso da protagonista, Oribela, distingue-se por querer ser ouvido e já não faz mais parte daquela produção em que a dicção feminina era ancorada "nas esferas do 'sentir' e do 'pressentir'" apenas (BRANCO; BRANDÃO, 1989, p. 87), aquele que não era levado em consideração. Conforme Branco e Brandão (1989), o texto feminino é construído a partir da lacuna do esquecimento, dos deslizamentos e de saltos inesperados. Palavras e atitudes que mostram como essa personagem, que age de maneira forte para adaptar-se a sua nova situação não quer ficar apenas na oralidade, como era antigamente uma característica do texto feminino, segundo Branco e Brandão (1989). Logo, a escrita feminina é uma das maneiras de impor-se e afirmar também a sua história, evidenciando uma influência benéfica para o campo da literatura bem como alterar o passado no tempo presente sem ser mediada pelo ponto de vista de um homem. As personagens femininas apresentam seus próprios ideais, ocupam territórios que outrora lhes eram proibidos e recuperam suas vozes por meio da literatura de autoria feminina.

Oribela igualmente não mais reproduz aquele velho discurso tradicional advindo de Portugal em que se julgava ser superior. Após sofrer os abusos matrimoniais e ver que na terra onde reside havia "padres famélicos, de feia tirania, nenhuma fé e maquiavam seus pecados de luxúria com peito insolente" (MIRANDA, 1996, p. 45) e presencia que o marido de outra órfã configurada, a dona Bernardinha, "fazia servir sua esposa por dinheiro [e] dela se ouviam gritos, deles risos, uns davam por isso uma moeda, outros um pedaço de uma qualquer coisa" (MIRANDA, 1996, p. 151), ela deseja extravasar seus sentimentos e sua irritação e não mais ser configurada por uma cultura eurocêntrica.

Nessa interação linguística atentamos para o fato de que o modo da protagonista narrar carrega consigo "uma linguagem amena, fluída e coloquial” (FLECK, 2017, p. 110), cujas frases apresentam-se de forma "curtas e elaboradas de preferência em ordem direta, e com um 
vocabulário mais voltado ao domínio comum que ao erudito.” (FLECK, 2017, p. 11). Ademais, Fleck (2017) explana que é possível modernizar a linguagem dos tempos passados para aproximar o leitor da obra, contudo algumas delas podem enfatizar a verossimilhança na narrativa e fazer uso de uma linguagem mais arcaica.

As falas da protagonista do romance são uma mistura dessas duas formas: curtas, mas verossímeis, pois temos como base a questão temporal já que a história se passa em meados do século XVI. A sua fala é direta, mas traz um som arcaico: "Fosse me conformando, que um dia seria eu, e todas, umas velhas à luz das panelas e se fomos feitas solamente para mães e esposas, a nos resignar cabe o coração, apenas. Mas se fomos assim feitas, por que a Velha freira de convento? Pois não seria eu feliz em tal lugar, senão em outro.” (MIRANDA, 1996, p. 135).

Outra característica importante no romance Desmundo (1996) é o emprego de algumas estratégias bakhtinianas, como "a dialogia, a polifonia, as intertextualidades, além, é claro da paródia” (FLECK, 2017, p. 111) que, segundo Fleck (2017), são essenciais na constituição dos romances históricos contemporâneos de mediação. Dentre essas damos ênfase à intertextualidade, onde um texto se faz presente em outro, como trecho da carta de achamento de Pero Vaz de Caminha (CASTRO, 2008) sobre as terras brasileiras que descrevia as mulheres encontradas no "Novo Mundo": “[...] aly amdavam antre eles tres ou quatro moças bem moças e bem jentijs com cabelos mujto pretos comprjdos pelas espadoas e suas vergonhas tam altas e tã çaradinhas e tam limpas das cabeleiras que de as nos mujto bem olharmos ño tínhamos nhuũa vergonha." (CAMINHA, apud CASTRO, 2008, p. 49, grifos nossos). Na carta de descobrimento, tal trecho era mediado pelo ponto de vista masculino. Na diegese romanesca, temos essa mesma ideia, todavia reproduzida por uma personagem feminina, a protagonista Oribela, que durante seu encontro com as nativas da terra narra o trecho, mas de uma forma surpreendente:

\footnotetext{
Por meus brios e horrores, não despreguei os olhares das naturais, sem defeitos de natureza que lhes pudessem pôr e os cabelos da cabeça como se forrados de martas, não pude deixar de levar o olhar as suas vergonhas em cima, como embaixo, sabendo ser assim também eu, era como fora eu desnudada, a ver em um espelho. Nunca fora dito haver mulheres assim, nem pudera inventar em minhas ignorâncias. (MIRANDA, 1996, p. 39, grifos nossos).
}

A sua versão desse fato histórico mostra-se chocante e escandalosa uma vez que como moça recatada ela nunca tinha observado seu próprio corpo, mas se vê forçada a fazer isso 
olhando o corpo de outra mulher e estabelece nesse falar a relação de intertextualidade. Ao estabelecer essa relação com a "Outra" - um ser considerado diferente racialmente, mas não sexualmente -, a personagem se descobre como mulher, algo que não lhe fora apresentado pela sua cultura europeia visto que ela tinha como única visão a imitação, internalização e reprodução de valores dominantes sobre si mesma. Ao reconhecer-se na "Outra" mulher indígena ela apresenta uma visão de alteridade - um ser diferente.

Cremos que a história da personagem Oribela tem seu próprio "tom” crítico, entre o tradicionalismo e a desconstrução, conforme defende Fleck (2017) como marca maior do romance histórico mais recente. Essa voz enunciadora busca ser ouvida para ser, então, compreendida. As percepções da protagonista não são romantizadas acerca do que enxerga, mas ela expressa sua perspectiva crítica em um discurso de tom dissonante daquele difundido pela historiografia oficial.

\section{A Mãe da Mãe da Mãe e Suas Filhas (2002), um romance contemporâneo de mediação -} enunciar a colonização brasileira por uma voz feminina como via de descolonização

A ficcionalização presente na obra A mãe da mãe da sua mãe e suas filhas (2002) traz à tona novas perspectivas a partir do olhar da mulher brasileira, proporcionando diferentes reflexões e compreensões sobre a trajetória da história brasileira e as diversas nuances possíveis da permanência dos traços de oralidade na formação do povo brasileiro. Tal aspecto, oriundo das tradições ancestrais dos povos nativos, permite que raízes identitárias sejam revisitadas e desabrochem no discurso ficcional. Desta forma, outras vozes desse passado esquecido e arraigado em dicotomias dos registros historiográficos eurocêntricos chegam aos ouvidos dos leitores na atualidade.

Ao reler fatos importantes do processo de formação do Brasil e da constituição de sua sociedade híbrida e mestiça, Silveira (2002) aponta para alguns momentos da história oficial do país, trazendo para a obra representações de personagens verossímeis e lhes dá o espaço da enunciação ao longo desses 500 anos de história. Nesse processo de releitura crítica são incorporados ainda aspectos relevantes da mestiçagem e as possíveis genealogias que foram surgindo ao longo da história brasileira, aportada no evidente entrecruzamento racial das três 
etnias que estruturam nossa história social. A partir dessa ótica, há o rompimento do discurso romanesco com o lema discursivo da colonização europeia na América Latina: "unidade e pureza". Silviano Santiago (1978) aborda a contribuição da América Latina para a cultura ocidental ao salientar que esta foi, especialmente, efetuada pela destruição sistemática dos conceitos de unidade e de pureza. Segundo o autor,

[...] estes dois conceitos perdem o contorno exato do seu significado, perdem seu peso esmagador, seu sinal de superioridade cultural, à medida que o trabalho de contaminação dos latino-americanos se afirma, se mostra mais eficaz. A América Latina institui seu lugar no mapa da civilização ocidental graças ao movimento de desvio da norma, ativo e destruidor, que transfigura os elementos feitos e imutáveis que os europeus exportavam para o Novo Mundo. (SANTIAGO, 1978, p. 16).

Em busca da libertação dos traços desse lema colonizador, as produções híbridas de história e ficção latino-americanas das últimas décadas ganham forças, ressaltando a busca pela independência cultural que os "colonizados" podem adquirir, mesmo que para isso tenham que valer-se dos experimentalismos, das diferenças linguísticas, sociais, culturais e políticas, de maneira que cada peculiaridade seja exaltada e, ao mesmo tempo, seja um elemento de distinção de nosso fazer literário.

Desse modo, a ressignificação do passado pela ficção evidencia o intenso processo de mestiçagem racial, hibridação cultural e sincretismo religioso que foram empreendidos pelos colonizadores portugueses, pelos autóctones - com os primeiros contatos seus com os recémchegados - e com os africanos - trazidos à força para os trabalhos forçados ao longo do processo de transformação da colônia em um espaço rentável à metrópole europeia. São esses elementos diferenciadores que fazem da obra de Silveira (2002) uma releitura crítica do passado colonial brasileiro.

A trajetória imaginada para as personagens femininas do romance de Maria José Silveira (2002) contempla o panorama geral da história do Brasil, desde os primeiros passos da colonização até os eventos recentes do período republicano. O relato é composto pelas experiências de vinte mulheres de uma mesma família, cujas memórias são revividas pela voz narrativa de uma enunciadora que, ao que tudo indica, vive na contemporaneidade. Embora a narradora não participe como personagem dos fatos na história, seus relatos tecidos por meio de digressões, a partir de seu tempo presente, em primeira pessoa (perspectiva autodiegética e voz 
heterodiegética), sobre as personagens, épocas e ambientes do passado são recriados no romance. Vejamos um fragmente desse discurso da narradora:

Está bem.

Se é assim que vocês querem, vamos contar a história das mulheres da família.

Mas vamos com calma.

O assunto é delicado, a família é complicada, e nem tudo foi beleza nesta história. Houve, claro, felicidades e amores, muitas lutas e conquistas, grandes realizações afinal, elas ajudaram a construir quase do nada este país. Mas houve também loucas, assassinas, muitas desgraças e tristezas. Grandes dores. Muitas mesmo.

Lembrem-se também, se for o caso, de que foram vocês que me pediram para contar, desta vez, a vida das mulheres. (SILVEIRA, 2002, p. 11).

Assim, a narradora revela a história linear da sua família - traço marcante dos romances contemporâneos de mediação (FLECK, 2017) - em uma saga marcada pela oralidade e pelas inúmeras batalhas travadas pela busca de espaço e resistência das personagens femininas. $\mathrm{O}$ assunto do relato são as histórias repassadas de mãe para filha que se tornaria, futuramente, mãe também e, desse modo, a trama familiar vai sempre ganhando novos capítulos, cenários, percalços e frutos para um país tão rico de raças e culturas familiares que se multiplicam e se misturam a cada página. Verificamos que, nessa manifestação inicial da voz enunciadora do romance, fica explícito ao leitor o "olhar visto de baixo" (SHARPE, 1992) para o passado, para a história brasileira, para que revivamos e recriemos outra história tão mais viva e presente, capaz de incluir não apenas os "heróis", mas o contingente todo que, com seu esforço, construiu a nação.

A narrativa se inicia ao "evocar cenas de um passado de vivo colorido" com a aproximação do nascimento de Inaiá (1500-1514), na região de Porto Seguro, Bahia, à medida que as caravelas portuguesas estão chegando: “À hora da véspera daquele 21 de abril, um monte alto e redondo foi avistado pelos marujos em rebuliço [...] no exato momento em que a mãe de Inaiá se dirigiu para o recanto da floresta que previamente escolhera para esse dia, [...]." (SILVEIRA, 2002, p. 18).

Ao fazer uso das escritas da Carta de Achamento (1500), de Pero Vaz de Caminha, a autora vale-se da intertextualidade para criar uma maior verossimilhança na obra:

Neste dia, a horas de véspera, houvemos vista de terra! Primeiramente dum grande monte, mui alto e redondo; e doutras serras mais baixas ao sul dele; e de terra chã, com 
grandes arvoredos: ao monte alto o capitão pôs nome - o Monte Pascoal e à terra - a Terra da Vera Cruz. ${ }^{4}$ (CAMINHA, 1500, p. 1).

No exato momento em que os portugueses lançam suas âncoras, nasce a autóctone Inaiá. A personagem cresce de maneira concomitante ao desenrolar da colonização. Esta seria uma das primeiras aborígenes a envolver-se com um conquistador português e iniciar a miscigenação racial, por meio de sua relação com a personagem Fernão, jovem personagem de extração histórica.

A partir do relato sobre a vida desse casal, há o conhecimento não apenas da cultura e riqueza de uma terra e de costumes de outra, mas o encantamento e a pureza de duas raças se entrecruzando, seja pelo desejo comum da aventura, forçadas ou movidas pela ambição. O que leva as índias a partirem pelo mundo com os portugueses importa menos que o aprendizado e a formação do povo brasileiro. Assim, o romance relata:

Em um ano Inaiá deu à luz. Chamou-a de Tebereté, e o pai balançou a cabeça satisfeito. Sim, eles estavam no paraíso, e vocês me perguntam se eles se amaram. O que é o amor, o que era o amor? Não ouso responder. Que eles certamente gostavam de transar um como o outro, que Fernão não procurou outras índias porque isso nem lhe passou pela cabeça, que os dois passavam horas rolando no chão entre as folhas, brincando e gemendo, que Fernão tomava banho no rio puxado por Inaiá, que queria melhorar o cheiro dele, que Inaiá só pensava em levá-lo para o sossego de sua rede, onde pudessem brincar sem as mordidas dos bichos nas folhas, tudo isso aconteceu assim. É isso o amor? Então, sim, eles se amaram. (SILVEIRA, 2002, p. 28-29).

Logo nesse primeiro episódio se evidencia a linguagem amena com a qual o romance se efetivará em toda sua extensão, atendendo a mais uma das principais características do romance histórico contemporâneo de mediação que "prima pelo emprego de uma linguagem simples e de uso cotidiano, em oposição ao barroquismo e ao experimentalismo linguístico dos novos romances históricos [...]" (FLECK, 2017, p. 110). Essa linguagem empregada pela narradora reflete, com muita clareza, o momento da enunciação, a temporalidade atual na qual está inserida a narradora "contadora de histórias". Ela não desconstrói ou reforça aqui a brutalidade da colonização e a imposição de uma cultura sobre a outra, mas, sutilmente, coloca em questão o encantamento e a sagacidade dos nativos que ensinaram muito aos colonizadores por pureza,

\footnotetext{
${ }^{4}$ Disponível em: http://objdigital.bn.br/Acervo_Digital/Livros_eletronicos/carta.pdf. Acesso em 08 jan. 2020.
} 
mas, também, pelo desejo de conhecer o novo.

De acordo com Freyre (1983, p. 93), na colonização do Brasil pelos portugueses, “as mulheres eram as primeiras a se entregarem aos brancos, as mais ardentes indo esfregar-se nas pernas desses que supunham deuses. Davam-se ao europeu por um pente ou um caco de espelho." Inaiá apresenta traços de subordinação apenas pelo seu papel na tribo, garantindo a satisfação e harmonia do casal durante toda a união. Porém de todas as personagens do romance, o destino matrimonial mais satisfatório é o dessa personagem.

Nessa perspectiva, A mãe da mãe da sua mãe e suas filhas (2002), não aborda apenas o tema da colonização do Brasil, mas também questiona a influência feminina ao longo de todo esse processo e sua atuação. O romance aborda a colonização e formação do povo brasileiro com um olhar apurado para as fragilidades e durezas, pois há personagens marcadas não por seu parentesco com algum homem, mas por sua importância na formação e história do Brasil. Distanciando-se do olhar masculino canônico e opressor, este é um romance histórico de mediação que reafirma a mulher no cenário latino-americano. Para Duarte (1990, p. 16), “as mulheres ampliam significativamente sua participação na literatura e nas artes em geral", fazendo assim com que haja uma necessidade em reformular a estética de cunho feminista para abranger todas as transformações que vem ocorrendo na sociedade.

Do relacionamento de Inaiá e Fernão nasce a mestiça Tebereté (1514-1548) e, assim, segue-se a trama linear com Sahy, (1531-1569), Filipa (1552-1584), Maria Cafuza (1579-1605), Maria Taiaôba (1605-1671), Belmira (1631-1658), Guilhermina (1648-1693), Ana de Pádua (1683-1730), Clara Joaquina (1711-1740), Jacira Antônia (1737-1812), Maria Bárbara (17731790), Damiana (1789-1822), Açucena Brasília/Antônia Carlota (1816-1906), Diana América (1846-1883), Diva Felícia (1876-1925), Ana Eulália (1906-1930), Rosa Alfonsina (1926-...), Lígia (1945- 1971), Maria Flor (1968-...). A obra deixa em aberto a história, visto que não há um fim em Maria Flor, a última personagem da obra, mas não a última descendente desta árvore genealógica, pois ela está grávida e abre espaço para reflexão do leitor sobre os frutos dessas mulheres e a intensa ligação e espírito de luta que os brasileiros carregam.

Em nossa análise, após a exposição da trajetória da personagem Inaiá, faremos a seleção de algumas destas personagens para uma abordagem mais direta e comentada, enquanto outras 
serão tangencialmente inseridas na sequência lógica que essas histórias proporcionam, realizando um recorte para as primeiras mulheres da família e início da colonização brasileira.

Sahy viveu durante a instituição do Governo Geral (1548-1580) no Brasil, estrutura que fora criada para substituir as capitanias hereditárias a fim de atender às novas peculiaridades da colônia. Esse foi o período em que

[...] os interesses e preocupações comuns aos administradores metropolitanos e aos colonos promoveram uma confluência entre as ações dos dois segmentos, visando o mesmo objetivo - a conquista e o domínio das novas terras. As dificuldades vividas, aliada à pressão dos franceses e às possíveis alianças que se desenhavam entre estes $\mathrm{e}$ alguns grupos indígenas preocupavam a Coroa. O quadro se agravava ante a incapacidade dos donatários efetivarem os projetos de povoamento e colonização, a ausência de mecanismos coordenadores das forças defensivas terrestres e navais e das ações coletivas voltadas para o mesmo objetivo - colonizar e garantir a posse da terra conquistada. Essa dificuldade decorria do fato das capitanias se constituírem em unidades independentes e os conflitos entre os capitães serem constantes. A decisão tomada pelo governo metropolitano foi a de intervir de forma mais efetiva através da criação de um Governo Geral no Brasil como forma de solucionar as ameaças internas e externas aos seus empreendimentos. (PARAISO, 2011, p. 5).

Foi, prioritariamente, neste período que os nativos estiveram sujeitos à escravidão e eram utilizados como mão de obra pela coroa portuguesa. Com o intuito de acelerar o processo de colonização e extração de produtos do Brasil, inúmeras pessoas foram enviadas para a terra papagaia: crianças, mulheres, padres, degredados, funcionários da coroa, soldados, entre outras pessoas.

Dentre estes estava Vicente Arcón, um castelhano que, ao andar pela costa da Bahia, encontrou Sahy e a capturou unicamente por assemelhar-se fisicamente a sua falecida esposa. Ainda que tenha visto nela uma chance de ter novamente sua cônjuge, a nativa foi escravizada para atender aos desejos sexuais de Vicente e também para preparar embutidos para a tropa de seu dono. Frente a essa realidade, a narradora comenta que a personagem "não sentia horror nem prazer com isso, não sentia nada. Se deixava trepar sem dramas, sem volteios, como quem come, respira, bebe água e faz as necessidades.” (SILVEIRA, 2002, p.49).

De acordo com Barros (2009) a sexualidade é trazida como força motriz para a colonização e formação do povo brasileiro, a mulher índia é destacada por ter um importante espaço nesse cenário, pois será ela quem formará o núcleo da família, reproduzindo com índios, europeus e dando vazão à miscigenação. Além disso, é ela quem provê os alimentos com o 
plantio, colheita e produção.

Novamente verificamos a amenidade da linguagem e também a linearidade narrativa, segunda característica postulada por Fleck (2017) para os romances históricos contemporâneos de mediação. Cronologicamente, a narrativa do romance segue os caminhos da colonização, inclusive a revisitação de locais centrais neste processo de acordo com o período em questão, seguindo uma das características dos romances históricos de mediação, conforme observado por Fleck (2017).

Embora aceitasse sua nova condição de escrava, Sahy era infeliz, sentia falta de sua tribo, mas sua personalidade a impedia de lutar, fazendo-a assistir, passivamente, os destinos que sua vida tomava. Dessa sua relação com Vicente nasceu Filipa, que deixou a vida da ameríndia Sahy mais feliz. Contudo, a infelicidade, sua cruel companheira, levou Sahy à morte e, após esse evento, sua filha de apenas dez anos foi levada a Recife por um comprador de escravos. No momento em que a personagem Filipa chegou a Pernambuco e viu a produção de açúcar "pensou estar vendo na terra o que o padre chamava de inferno.” (SILVEIRA, 2002, p.58). Seu maior desejo era fugir.

A organização linear da narrativa, de acordo com os eventos históricos cronologicamente organizados, o olhar "visto de baixo" (SHARPE, 1992), para esse passado numa perspectiva centralizada, a linguagem fluida e amena do romance, a construção da verossimilhança, já são indícios seguros que nos possibilitam classificar a obra dentro da terceira fase do romance histórico - a crítica, na escrita mediadora - (FLECK, 2017).

Com base na premissa portuguesa a expansão do catolicismo, assim que os nativos eram negociados, o batismo era realizado para evitar o paganismo. Em vista disso, as raízes da nação brasileira se constroem numa relação paradoxal: de um lado a religiosidade católica fervorosa dos europeus e de outro a exploração, comercialização e escravização dos nativos pelos cristãos que aqui aportavam. Com a queda da produção de pau-brasil, foi necessário iniciar uma nova atividade lucrativa e que atraísse novos colonizadores portugueses, iniciando o ciclo da cana de açúcar. Os nativos "negros da terra" eram bons para o desmatamento e preparação do solo, porém era cada vez mais necessária a vinda de mão de obra africana para realizarem o trabalho completo do engenho. 
Neste novo cenário da colonização aparece, na diegese elaborada pela autora, a personagem Mb'ta, um negro da Guiné. Ele fora capturado e trazido ao Brasil em um porão de navio negreiro. Seu único pensamento era fugir. Após alguns anos trabalhando juntos no mesmo engenho, os martírios da escravidão e o desejo de fuga juntam Mb'ta e Filipa, nascendo deste relacionamento Maria Cafuza. Pelo relato de Silveira (2002), vemos que a personagem Maria Cafuza (1579-1605) viu a morte sanguinária de seus pais, aos cinco anos de idade, pelo capitão do mato, João Tibiritê, o que lhe tirara o brilho dos olhos. A criança fica aos cuidados de Manu Taiaôba e uma velha índia.

Quando entrou no acampamento, a menina já apagara para sempre de sua mente tudo o que vira até então, até a fala. Em seu peito só ficara a opressão esmagadora do sentimento convulsivo de ódio contra João Tibiritê. Sua vida, desde então, foi só e exclusivamente viver para se consumir por esse ódio. Ela cresceu no bando, sem falar e como se não escutasse, como bicho selvagem. [...] Via os combates, o tempo todo ruminando sua única idéia, sua obsessão, alimento, água e modo de respirar: a idéia de matar João. (SILVEIRA, 2002, p. 69).

Anos mais tarde, após uma noite de bebedeira de João Tibiritê, Maria realizou seu maior objetivo de matar o assassino de seus pais. Após ter a morte vingada Maria Cafuza teve um relacionamento com o paulista Manu, assim nasce Maria Taiôba, uma criança que almeja modificar a saga de sua família, traçando desde cedo um futuro diferente da sua mãe: começou a frequentar a escola.

Embora a simbologia da fala seja a força motriz do romance, ela, na tessitura da narrativa, não é concedida diretamente às personagens em nenhum momento. Ficando isso ao encargo da narradora - situada no tempo presente da enunciação -, uma vez que é ela quem conta aos leitores as conversas e os desejos mais profundos de cada uma das personagens da saga familiar. Tal aspecto estrutural do romance reforça o caráter não pluriperspectivisto e colabora para a nossa convicção de que essa obra é um exemplar da modalidade do romance histórico contemporâneo de mediação que, segundo Fleck (2017), adota, justamente, essas estratégias estruturais mais tradicionais.

$\mathrm{Na}$ sequência da narrativa vemos que o pai da personagem decidiu deixar a filha com a índia e alguns empregados na cidade e voltar para a vida na floresta, fazendo-lhe visitas periódicas. Em uma das visitas descobriu que sua filha iria se casar com Bento Diogo de Sá, 
nascido no Brasil, filho de português com mãe também portuguesa enviada pela rainha dona Catarina para ajudar a povoar o Brasil.

Devido ao constante crescimento da cultura da cana de açúcar no Brasil, muitas pessoas vieram de Portugal à colônia. Como nesta imigração poucas mulheres portuguesas vinham ao Brasil; a Coroa, para suprir a falta de portuguesas, brancas e cristãs para gerarem famílias “descentes”, enviava mulheres órfãs para se casarem no Brasil, evitando, também, a crescente mestiçagem entre português e índios, ou negros. Conforme descreve a narradora, a mãe de Bento Diogo de Sá - uma das órfãs da rainha, enviada ao Brasil para aqui se casar - era "moça saudável e submissa [...] só fez uma coisa na vida: cumprir a missão que lhe dera a rainha, isto é, parir. Bento Diogo foi o décimo segundo filho de um total de catorze”. (SILVEIRA, 2002, p, 80).

No entanto, a miscigenação ocorreu em larga escala e se tornou a constante mais visível de nossa sociedade e a narrativa ficcional de Silveira (2002) age com o intuito de recuperar essa memória coletiva do povo brasileiro.

O casamento não durou muito, pois Bento faleceu em seguida. Pouco tempo depois a personagem Taiaôba conhece Duarte Antônio de Oliveira, jovem de vinte e três anos, enviado de Portugal pelos pais para tentar a vida no Brasil e juntos criam um grande engenho de açúcar, sendo possível largar seu emprego de escrivão para dedicar a produção da cana, até 1630, quando os holandeses chegaram a Pernambuco dando início a guerra. "A recém nascida Belmira (16311658) chorou desesperada a noite toda, como se pressentisse as desgraças de sua vida de menina nascida na guerra e nela criada" (SILVEIRA, 2002, p. 85).

Há nas personagens femininas de $A$ mãe da mãe da sua mãe e suas filhas (2002) uma importante característica, o poder de transformação dessas mulheres de uma geração à outra. São elas constituídas de uma psique que revela personalidades superiores às barreiras. São figurações de mulheres donas de sua história, responsáveis pela criação das filhas, ainda que, para isso, tenham que confrontar-se com os mais extremos perigos e situações, como as invasões holandesas, que, para Fausto (1996, p. 84) "não se resumiram a um simples episódio regional. Ao contrário, fizeram parte do quadro das relações internacionais entre os países europeus, revelando a dimensão da luta pelo controle do açúcar e das fontes de suprimento de escravos.”.

Esse episódio se passa durante o período da invasão holandesa e a narradora relata que, 
após muitas das batalhas travadas entre as duas nações na colônia, o sucesso resultou favorável aos invasores holandeses. Nesse contexto de batalhas, travadas entre as forças portuguesas e os invasores holandeses, a personagem feminina deste episódio da história colonial brasileira Maria Taiaôba - não ficou à margem dos acontecimentos, reclusa em sua casa, cuidando das filhas. Segundo a narrativa,

\begin{abstract}
Maria Taiaôba aprovava a posição do marido. Achava certo não se forçar a escolher entre dois domínios estrangeiros. [...] Quando as batalhas eram em locais próximos, elas iam cuidar dos feridos, carregando seus cestos de ervas. Maria levava também escravos para cavar sepulturas e enterrar os mortos [...] muitas vezes chegavam tarde demais, quando apenas um odor pestilento se espalhava no ar [...]. No movimento de pessoas que passavam e muitas vezes pernoitavam no engenho de Duarte e Maria, as notícias da guerra iam e vinham, de um lado e de outro. (SILVEIRA, 2002, p. 91).
\end{abstract}

Para as personagens Maria Taiôba e Duarte não havia motivos para lutar e escolher quem dominaria os engenhos, pois para eles a terra era de quem aqui nasceram. Após a morte de Manu Taiaôba no mato e da Velha, Maria e Belmira ficaram no comando do engenho tentando resistir a mais uma guerra. Durante as batalhas um soldado recém-chegado, Wilhelm, adoeceu perto do engenho de Taiaôba e ali ficou aos cuidados de Belmira até reestabelecer-se. Logo se apaixonaram e, na mesma velocidade, o soldado foi morto na conhecida Batalha dos Gararapes. Contudo, dessa união nasceu Guilhermina (1648-1683), menina de pele clara, cabelos vermelhos e olhos castanhos; personagem que dará seguimento à saga familiar feminina da narradora.

Cansada da guerra e preocupada com o destino de sua filha e da neta, a personagem Maria Taiaôba deixa o engenho e parte para Salvador. Lá abre um negócio de aluguel de escravos e quando a guerra acaba, com o acordo feito com o lavrador que se apossou das terras de Maria, compra uma taberna e segue o ritmo da vida com neta e filha, até a morte de Belmira.

A mãe da mãe da sua mãe e suas filhas (2002) enquadra-se perfeitamente no romance histórico contemporâneo de mediação, trazendo a ficcionalidade e a história caminhando juntas em uma linha tênue. Há a aproximação histórica por meio de seu fundo, personagens e contextos da ficção literária, fazendo com que a crítica ao passado seja fina e sutil, relendo a história da formação brasileira pelo olhar da margem, mulheres negras, índias, mestiças, cafuzas, mulheres brasileiras que passam despercebidas pela histórica canônica, branca e opressora. Conhecendo o passado é possível rever o presente de maneira mais atenta, permitindo que todos os tipos de 
leitores leiam e compreendam a obra e sua postura frente o social.

\section{Considerações finais: entrecruzamento de histórias, sempre em movimento}

Fleck (2007, p. 154) afirma que no continente latino-americano "o romance histórico encontrou um dos solos mais férteis. $\mathrm{Na}$ mente dos nossos literatos, ele não só aflorou como também adquiriu uma força de expressão como em nenhuma outra parte do mundo." Conforme o autor, a literatura latino-americana tentava-se libertar do jugo dos países que eram considerados dominantes. Assim, novas escritas surgem para evidenciar áreas não observadas anteriormente.

$\mathrm{O}$ ato de escrever textos híbridos de história e ficção, atualmente, significa estar consciente de que, tanto a história quanto a literatura são campos constituídos de palavras e signos linguísticos que se combinam a fim de elaborar o discurso que convém proferir, sejam eles tradicionais ou desconstrutivos. Consequentemente, nesse processo de escrita e reescrita, recuperar a invisibilidade da autoria feminina desestabiliza paradigmas estabelecidos e propicia o surgimento um espaço "seu” no qual a mulher é sujeito de sua escrita.

As narrativas Desmundo (MIRANDA, 1996) e A mãe da mãe da sua mãe e suas filhas (SILVEIRA, 1996) revisitam o passado de uma maneira crítica, sem experimentalismos linguísticos ou formais, ou recursos altamente desconstrucionistas como a carnavalização, as ironias, anacronismos e apelos ao grotesco. No entanto, seu discurso desmantela a neutralidade e univocidade do discurso patriarcal e ampliam perspectivas de análise que não foram observadas pelo viés historiográfico tradicional e dominante. Conforme Zolin (2009), as obras de autoria feminina marcam a construção de novos saberes - novas percepções, novos sentimentos e novas atitudes. Observamos que elas recuperam a voz de inúmeras figuras femininas relegadas à inferioridade e à passividade do discurso eurocêntrico. Logo, escrever tornou-se um imperativo às mulheres, pois essa prática representa para elas a possibilidade de superação de uma fase de anonimato e ocultação. Nesse cenário, a literatura de autoria feminina no Brasil caracteriza-se pela busca e pela construção de uma identidade própria.

A verdadeira democratização do acesso à aprendizagem da leitura e da escrita ainda hoje não é geral nos países latino-americanos. No Brasil, faz apenas 130 anos que as mulheres, 
afrodescendentes e indígenas têm direito a frequentar uma escola. Na América Latina a trajetória da leitura e da escrita está estritamente vinculada a todo o sistema que representou o processo de colonização: dominação, imposição, exploração e subjugação. A mulher, nesse processo histórico, conforme destacou Guerra (2007), foi duplamente colonizada, sofrendo as imposições tanto de um como de outro lado do poder patriarcal. Revidar esse status é o que muitas autoras, como Ana Miranda (1996) e Maria José Silveira (2002) estão colocando em prática por meio de suas escritas.

\section{Referências}

ALMEIDA, Suely Creusa Cordeiro. O sexo devoto: normatização e resistência feminina no Império Português - XVI-XVIII. 2003. 332 f. Tese (Doutorado em História) - Centro de Filosofia e Ciências Humanas, Universidade Federal de Pernambuco, Recife, Pernambuco.

BARROS, João de Deus Vieira. Imaginário da brasilidade em Gilberto Freyre. 2. ed. São Luiz/MA: EDUFMA, 2009.

BOURDIEU, Pierre. A dominação masculina. Rio de Janeiro: Bertrand Brasil, 2014.

BRANCO, Lúcia Castello; Brandão, Ruth Silviano. A mulher escrita. Rio de Janeiro: Casa-Maria Editorial: LTC-Livros Técnicos e Científicos, 1989.

BRANCO, Lúcia Castello. O que é escrita feminina? São Paulo: Brasiliense, 1991.

CASTRO, Silvio. A carta de Pero Vaz de Caminha. Porto Alegre: L\&PM, 2008.

COSTA, Afonso. As órfãs da rainha. Revista do instituto histórico geográfico brasileiro. v. 190, p. 105-111, jan./mar., 1946.

DUARTE, Constância Lima. Literatura feminina e crítica literária. In: Mulher e literatura. Travessia, n.21, p.15-23, Santa Catarina: UFSC, 1990.

FAUSTO, Boris. História do Brasil. São Paulo: Edusp, 1996.

FLECK, Gilmei Francisco. A conquista do "entre-lugar": a trajetória do romance histórico na América. Gragoatá, Niterói, n. 23, p. 149-167, jul./dez. 2007.

FLECK, Gilmei Francisco. O romance histórico contemporâneo de mediação: entre a tradição e o desconstrucionismo - releituras críticas da história pela ficção. Curitiba: CRV, 2017. 
FREYRE. Gilberto. Casa grande \& senzala. Rio de Janeiro: José Olympio, 1983.

GARCIA, Rodolfo. As órfãs. Revista do instituto histórico geográfico brasileiro. v. 192, p. 137143, jul./set., 1946.

GUERRA, Lucia. Mujer y escritura: fundamentos teóricos de la crítica feminista. México, D. F: Universidade Autónoma de México, 2007.

HUTCHEON, Linda. A poética do pós-modernismo: história teoria e ficção. Rio de Janeiro: Imago, 1991.

MATA INDURÁIN, Carlos. Retrospectiva sobre la evolución de la novela histórica. In: SPANG, Kurt; ARELLANO, Ignacio; MATA INDURÁIN, Carlos. (org.) La novela histórica: teoria y comentarios. Pamplona: EUNSA, 1995. p. 13-64.

MILTON, Heloísa Costa. As histórias da história: retratos literários de Cristóvão Colombo. 1992. 189f. Tese (Doutorado em Letras) - Universidade de São Paulo, Faculdade de Filosofia, Letras e Ciências Humanas. São, Paulo, 1992.

MIRANDA, Ana. Desmundo. São Paulo: Companhia das Letras, 1996.

PARAISO, Maria Hilda Baqueiro. Revoltas indígenas, a criação do governo geral e o regimento de 1548. In: História Colonial. Clio, revista de pesquisa histórica. v. 29. n. 1. Recife, 2011. p. 121

PERROT, Michelle. Minha história das mulheres. São Paulo: Contexto, 2012.

PESAVENTO, Sandra Jatahy. Fronteiras da ficção: diálogos literários da história com a literatura. Anais do XX simpósio nacional de história-ANPUH. v. 2, p. 819-831, jul., 1999.

RAMOS, Fábio Pestana. A história trágico-marítima das crianças nas embarcações portuguesas do século XVI. In: DEL PRIORI, Mary (org.). História das crianças no Brasil. 6. ed. São Paulo: Contexto, 2007. p.19-54.

QUIJANO, Aníbal. Colonialidade do poder, Eurocentrismo e América Latina. In: LANDER, Edgardo. (org.) A colonialidade do saber: eurocentrismo e ciências sociais. Perspectivas latinoamericanas. Buenos Aires: CLACSO, 2005. p. 117-142.

SANTIAGO, Silviano. Uma literatura nos trópicos. 2. ed. Rio de Janeiro: Rocco, 2000.

SHARPE, Jim. A história vista de baixo. In: BURKE, Peter (org.). A escrita da história: novas perspectivas. São Paulo: UNESP, 2011. p. 39-63. 


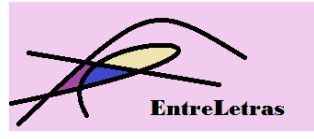

Revista ENTRELETRAS (Araguaína), v. 11, n. 1, jan./abr. 2020 (ISSN 2179-3948 - online)

SHOWALTER, Elaine. A literature of their own: British women novelists from Brontë to Lessing. New Jersey: Princeton UP, 1985.

SILVEIRA, Maria José. A mãe da mãe da sua mãe e suas filhas. São Paulo: Globo, 2002.

VAINFAS, Ronaldo. Homoerotismo feminino e o santo ofício. In: PRIORI, Mary (org.). História das mulheres no Brasil. 10. ed. São Paulo: Contexto, 2011.

ZOLIN, Lúcia Osana. Literatura de Autoria Feminina. In: BONNICI, Thomas; ZOLIN, Lúcia Osana (org.). Teoria literária: abordagens históricas e tendências contemporâneas. 3. ed. Maringá: Eduem, 2009. p. 327-336.

Recebido em 20 de janeiro de 2020

Aceito em 28 de abril de 2020 